\title{
Spawanie laserowe rur ożebrowanych ze stali martenzytycznej P91
}

\section{Laser welding of P91 martensitic steel finned tubes}

\section{Streszczenie}

Wzrost zapotrzebowania na energię elektryczną w Europie wymaga ciągłego poszukiwania nowych źródeł energii, rozwiązań konstrukcyjnych oraz technologicznych. Utrzymanie dotychczasowego poziomu produkcji energii elektrycznej wymaga modernizacji eksploatowanych jednostek oraz budowy nowych bloków na parametry nadkrytyczne i ultranadkrytyczne. Podwyższenie sprawności termicznej przy jednoczesnej redukcji kosztów energii możliwe jest dzięki zastosowaniu rur ożebrowanych na wymienniki ciepła. W pracy przedstawiono technologie wytwarzania rur ożebrowanych, ze szczególnym uwzględnieniem innowacyjnej technologii spawania laserowego opracowanej w Energoinstal SA. Wykorzystanie laserów dyskowych dużej mocy pozwala na spawanie rur ożebrowanych ze stali martenzytycznej P91. Rury takie są elementem wymienników ciepła o dużym potencjale stosowania, ze względu na właściwości, żarowytrzymałość i żaroodporność. W pracy przedstawiono wyniki prób technologicznych spawania laserowego rur ożebrowanych ze stali P91 przeprowadzone w Energoinstal SA. Stwierdzono, że opracowany sposób spawania laserowego spełnia wymagania jakości i może być rozważany do kwalifikowania technologii spawania stali P91 bez obróbki cieplnej.

Słowa kluczowe: rury ożebrowane; spawanie laserowe; stal P91

\begin{abstract}
The increase in demand for electric power in Europe necessitates constant research into new sources of energy and constructional and technological solutions. Maintaining the current level of electric power generation requires the modernization of units which are currently in service and the construction of new supercritical and ultra-supercritical power units. Increasing thermal efficiency while reducing the cost is possible due to the use of finned tubes in heat exchangers. This work describes finned tube production technologies with a particular emphasis on the innovative laser welding technology developed at Energoinstal S.A. The use of high-power disk lasers enables welding of finned tubes made of the P91 martensitic steel. Laser-welded finned tubes of P91 are heat exchanger components with a high potential for application due to their creep and heat resistance. The paper presents the results of technological tests of laser welding of P91 finned tubes, performed at Energoinstal SA. It has been found that the laser welding technology developed meets the relevant quality requirements and may be considered in terms of qualification of the P91 welding procedure without heat treatment.
\end{abstract}

Keywords: finned tubes; laser welding; P91 steel

\section{Wprowadzenie}

Głównym kierunkiem rozwoju kotłów parowych jest ciągła poprawa i optymalizacja ich konstrukcji. Wysokie sprawności, ponad $50 \%$ osiągają kotły gazowe oraz kombinowane układy parowo-gazowe (ang. HRSG - Heat Recovery Steam Generator), które wykorzystują m.in. spawane rury ożebrowane [1]. Istnieje konieczność budowy bloków parowo-gazowych jako źródeł o dużej dyspozycyjności i elastyczności przy zachowaniu niskiej ich awaryjności oraz bloków na parametry nadkrytyczne jako elementów energetyki zawodowej [1].

Rury ożebrowane są stosowane głównie w kotłach gazowych i gazowo-parowych, gdzie charakterystyczny jest duży strumień gorących spalin. Spaliny te dostarczają ciepło do wszystkich wymienników tj. do podgrzewaczy wody, parowników i przegrzewaczy pary [3,4]. Aby odebrać taką ilość energii, wymienniki ciepła muszą charakteryzować się wysoką sprawnością cieplną. Sprawność wymiany ciepła zależy od współczynnika przewodzenia pomiędzy ścianką rury a spalinami, a tym samym od pola powierzchni wymiany tj. powierzchni rury [5]. Sposobem na zwiększenie sprawności jest zastosowanie spawanych rur ożebrowanych w wymiennikach ciepła. To rozwiązanie istotnie zwiększa powierzchnię wymiany ciepła, umożliwiając pełną optymalizację powierzchni ogrzewalnych kotła [6].

Mgr inż. Katarzyna Łyczkowska; dr hab. inż. Janusz Adamiec, prof. PŚI - Politechnika Śląska

Autor korespondencyjny/Corresponding author: katarzyna.lyczkowska@polsl.pl 
Spawane rury ożebrowane istotnie (trzykrotnie) zwiększają sprawność wymienników ciepła, co jest głównie spowodowane rozwinięciem powierzchni wymiany. Konieczne jest jednak uzyskanie połączenia metalicznego pomiędzy rurą a żebrem. Z punktu widzenia sprawności cieplnej rur ożebrowanych nie ma znaczenia zastosowana technologia spawania a jedynie ciągłość połączenia. Jednak ze względu na proces technologiczny wytwarzania rur, jego koszty 5 oraz prawdopodobieństwo wystąpienia niezgodności spawalniczych, a także warunki pracy rur ożebrowanych (ciśnienie medium, temperatura gazów, korozja wysokotemperaturowa, naprężenia cieplne i mechaniczne) bardzo ważnym czynnikiem decydującym o jakości jest technologia spawania. Technologia spawania powinna zapewnić uzyskanie połączenia rura - żebro z pełnym przetopieniem na całej długości złącza.

Rury ożebrowane są wytwarzane różnymi metodami w zależności od ich konstrukcji (rys. 1). Konstrukcje rur ożebrowanych można podzielić na: rury dzielone, w których nie ma połączenia ciągłego (metalicznego) żebra z rurą oraz na rury charakteryzujące się ciągłym połączeniem metalicznym pomiędzy żebrem a rurą. Do technologii wytwarzania rur z połączeniem dzielonym zalicza się głównie mechaniczne zaciskanie taśmy, natomiast do technologii pozwalających uzyskać ciągłe metaliczne połączenie zalicza się technologie przeróbki plastycznej i technologie spajania. Analiza parametrów pracy wymienników ciepła zbudowanych ze spawanych rur ożebrowanych wskazuje, że rura najczęściej jest wykonana z podstawowych stali dla energetyki o strukturze ferrytyczno-perlitycznej typu P235, P265 lub P355 oraz stali z dodatkiem molibdenu 15Mo3 i z dodatkiem chromu 13CrMo4-5 i 10CrMo9-10. Jako taśmę stosuje się niskowęglowe stale typu DC01, DC02, DC03 lub DC04 oraz X2CrTi12. Dobór gatunku rury i żebra jest uzależniony od warunków pracy wymiennika ciepła.

W artykule przedstawiono technologię spawania laserowego rur ożebrowanych ze stali P91, które są przewidziane do pracy w kotłach na parametry nadkrytyczne.

\section{Materiał do badań}

Do prób technologicznych wykorzystano rury ze stali P91 o średnicy $38 \times 2,9$ mm oraz płaskownik w formie taśmy o wymiarach $15 \times 1,0 \mathrm{~mm}$ ze stali $1.4512 \mathrm{wg}$ 10088-2. Skład chemiczny oraz właściwości mechaniczne materiału do badań zestawiono w tablicy I.

\section{Technologie wytwarzania rur ożebrowanych}

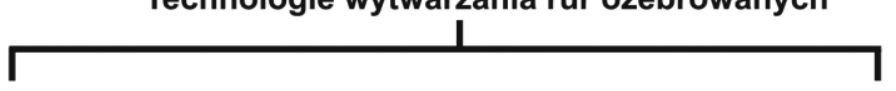

Połączenie dzielone żebro -rura<smiles>[CH][TeH]</smiles>

Mechaniczne zaciskanie

- Nawijanie taśmy na gładką rurę rdzeniową

Nawijanie taśmy na rurę rdzeniową o powierzchni radełkowej

- Nawijanie taśmy podwójnie zakładanej na rurze rdzeniowej

- Nawijanie taśmy w rowku zaciskowym wykonanym na rurze rdzeniowej

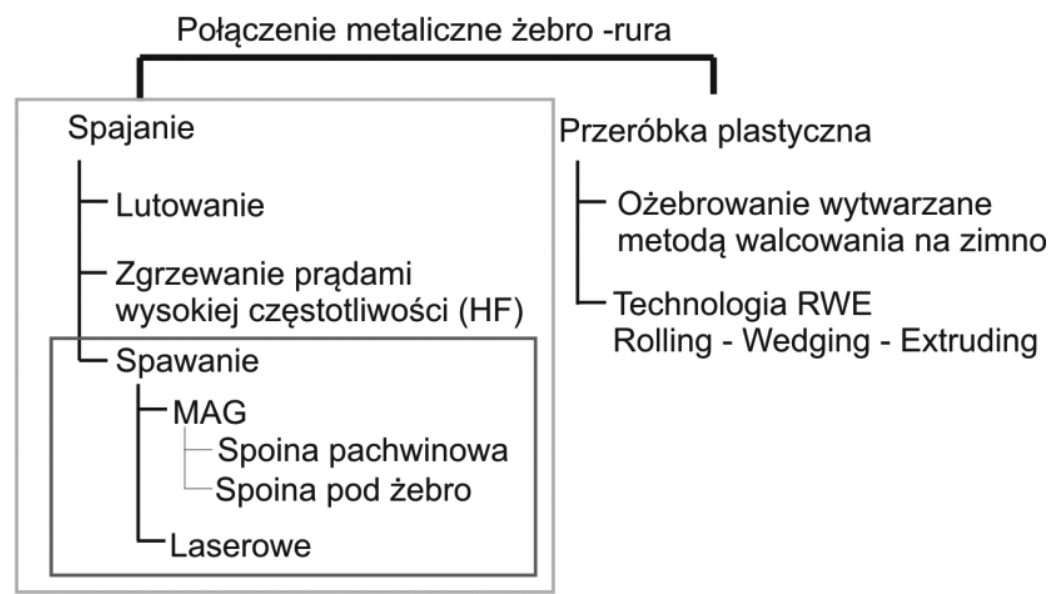

Rys. 1. Podział technologii wytwarzania rur ożebrowanych [7]

Fig. 1. Classification of finned tube production technologies [7]

Tablica I. Skład chemiczny i właściwości materiałów użytych do prób technologicznych spawania rur ożebrowanych Table I. Chemical composition and properties of materials used for the technological tests of welding of finned tubes

\begin{tabular}{|c|c|c|c|c|c|c|c|c|c|c|c|c|c|}
\hline \multirow{2}{*}{$\begin{array}{l}\text { Materiał } \\
\text { wytop }\end{array}$} & \multicolumn{13}{|c|}{ Skład chemiczny [\% wag.] } \\
\hline & C & Mn & $\mathbf{P}$ & s & $\mathrm{Si}$ & $\mathrm{Cr}$ & $\mathrm{Ni}$ & Al & Mo & $\mathrm{Nb}+\mathrm{Ta}$ & $\mathrm{Ti}$ & Co & $\mathrm{Fe}$ \\
\hline $\begin{array}{c}\text { Rura } 38 \text { x 2,9 } \\
\quad 709855\end{array}$ & 0,11 & 0,47 & 0,014 & 0,001 & 0,32 & 8,30 & 0,24 & 0,018 & 0,91 & 0,071 & - & - & reszta \\
\hline $\begin{array}{c}\text { Taśma } 15 \times 1,0 \\
0521564\end{array}$ & 0,010 & 0,25 & 0,022 & 0,001 & 0,45 & 11,66 & 0,23 & - & 0,020 & 0,010 & 0,22 & - & reszta \\
\hline \multirow{2}{*}{\multicolumn{4}{|c|}{ Materiał }} & \multicolumn{10}{|c|}{ Właściwości mechaniczne w temp. $20^{\circ} \mathrm{C}$} \\
\hline & & & & \multicolumn{3}{|c|}{$\mathbf{R}_{\mathrm{e} 02}[\mathrm{MPa}]$} & \multicolumn{4}{|c|}{$\mathbf{R}_{\mathrm{m}}[\mathrm{MPa}]$} & \multicolumn{3}{|c|}{$\mathrm{A}_{5}[\%]$} \\
\hline \multicolumn{4}{|c|}{ Rura 38 x 2,9 - P91 } & \multicolumn{3}{|c|}{534} & \multicolumn{4}{|c|}{678} & \multicolumn{3}{|c|}{23} \\
\hline \multicolumn{4}{|c|}{ Taśma 15 x 1,0 - 1.4512} & \multicolumn{3}{|c|}{250} & \multicolumn{4}{|c|}{422} & \multicolumn{3}{|c|}{33} \\
\hline
\end{tabular}




\section{Próby technologiczne spawania laserowego rur ożebrowanych}

Automatyczne stanowisko do spawania rur ożebrowanych opracowane $w$ Energoinstal SA składa się z lasera dyskowego TRUDISK 8002 firmy Trumpf z układem podziału wiązki laserowej na dwa stanowiska spawalnicze, wyposażone w systemy obrotu i posuwu rur podczas spawania oraz automatyczny system malowania. Schematycznie układ spawania pokazano na rysunku 2.

Laser TRUDISK 8002 został wyposażony w dwa światłowody od długości $30 \mathrm{~m}$, co w połączeniu z dwoma głowicami spawalniczymi umożliwia spawanie przemienne na każdej z linii stanowiska. Taki układ powoduje maksymalizację wykorzystania pracy lasera. Podczas spawania na linii nr 1, na drugiej linii trwa przygotowanie następnej rury. Układ transportu rur umożliwia ich przemieszczanie z prędkością liniową do $5 \mathrm{~m} / \mathrm{min}$ oraz przy prędkości obrotowej rury $350 \mathrm{obr} / \mathrm{min}$ Zakres długości spawanych rur to od 3 do $24 \mathrm{~m}$, przy zachowaniu wybiegów od 50 do $250 \mathrm{~mm}$. Istotnym czynnikiem decydującym o możliwości spawania rur ożebrowanych z prędkością obrotową powyżej 100 obr/min jest układ pozycjonowania głowicy spawającej. Zaprojektowany został układ trójosiowy z płynną regulacją w każdej osi, dzięki czemu uzyskano możliwość dokładnej regulacji położenia głowicy laserowej, automatycznego sczepiania taśmy przed rozpoczęciem procesu spawania oraz automatycznego odcinania taśmy wiązką laserową po zakończeniu procesu spawania. W celu podgrzewania rur przed spawaniem zaprojektowano system indukcyjnego podgrzewania rur, który w stosunku do podgrzewania gazowego pozwala na pełną regulację i kontrolę

a)
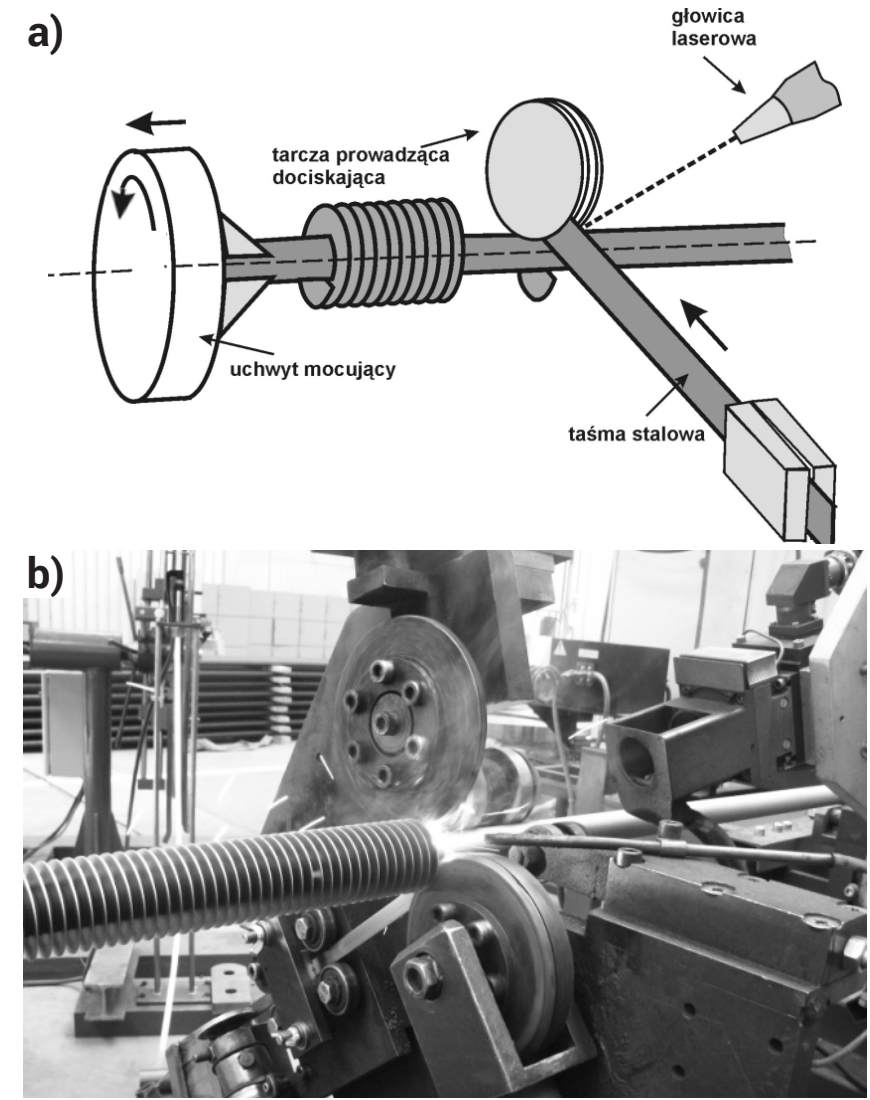

Rys. 2. Laserowe stanowisko do spawania rur ożebrowanych opracowane w Energoinstal SA: a) schemat ogólny układu spawania, b) spawanie laserowe rur

Fig. 2. A laser workstation for welding of finned tubes, designed at Energoinstal SA: a) general diagram of the welding system, b) laser welding of tubes temperatury podgrzewania wstępnego. System ten jest zintegrowany z całą linią i umożliwia nagrzewanie rury o średnicy $\varnothing 44,5$ i grubości ścianki $5 \mathrm{~mm}$ do temperatury $300{ }^{\circ} \mathrm{C}$ przy prędkości liniowej posuwu $5 \mathrm{~m} / \mathrm{min}$.

W Energoinstal SA przeprowadzono próby spawania laserowego rur ze stali P91 z żebrem ciągłym nawijanym ze stali 1.4512 bez materiału dodatkowego. Prędkość obrotowa rury była w zakresie $40 \div 100 \mathrm{obr} / \mathrm{min}$, spawanie prowadzono w osłonie argonu przy przepływie $5 \mathrm{l} / \mathrm{min}$ a odległość ogniskowej wiązki laserowej wynosiła $180 \mathrm{~mm}$ od powierzchni rury. Stosowano wiązkę o mocy w zakresie $1,4 \div 2,8 \mathrm{~kW}$. Liczba żeber na $1 \mathrm{mb}$ wynosiła $155 \mathrm{szt}$. (podziałka 6,45 mm) oraz 270 szt. (podziałka 3,70 mm).

\section{Wyniki badań złączy spawanych laserowo rur ożebrowanych ze stali P91}

Badania wizualne wykonane zgodnie z wymaganiami normy EN ISO 17637 wykazały, że spoina jest ciągła na całej długości rury, charakteryzuje się równomiernym licem, bez odprysków oraz pełnym przetopieniem (rys. 3a). Uzupełnieniem badań wizualnych była ocena makrostruktury (rys. 3b). Wyniki tych badań potwierdziły, że złącze jest wykonane prawidłowo, z pełnym przetopieniem, prawidłowym przejściem lica spoiny w materiał rodzimy (rys. 3b). Nie ujawniono niezgodności spawalniczych w postaci pęknięć, braków ciągłości spoiny itp. Na tej podstawie złącze zakwalifikowano do poziomu jakości B wg PN-EN ISO 13919, co wskazuje, że spawane laserowo rury ożebrowane ze stali P91 mogą być używane w wymiennikach ciepła dla przemysłu energetycznego.
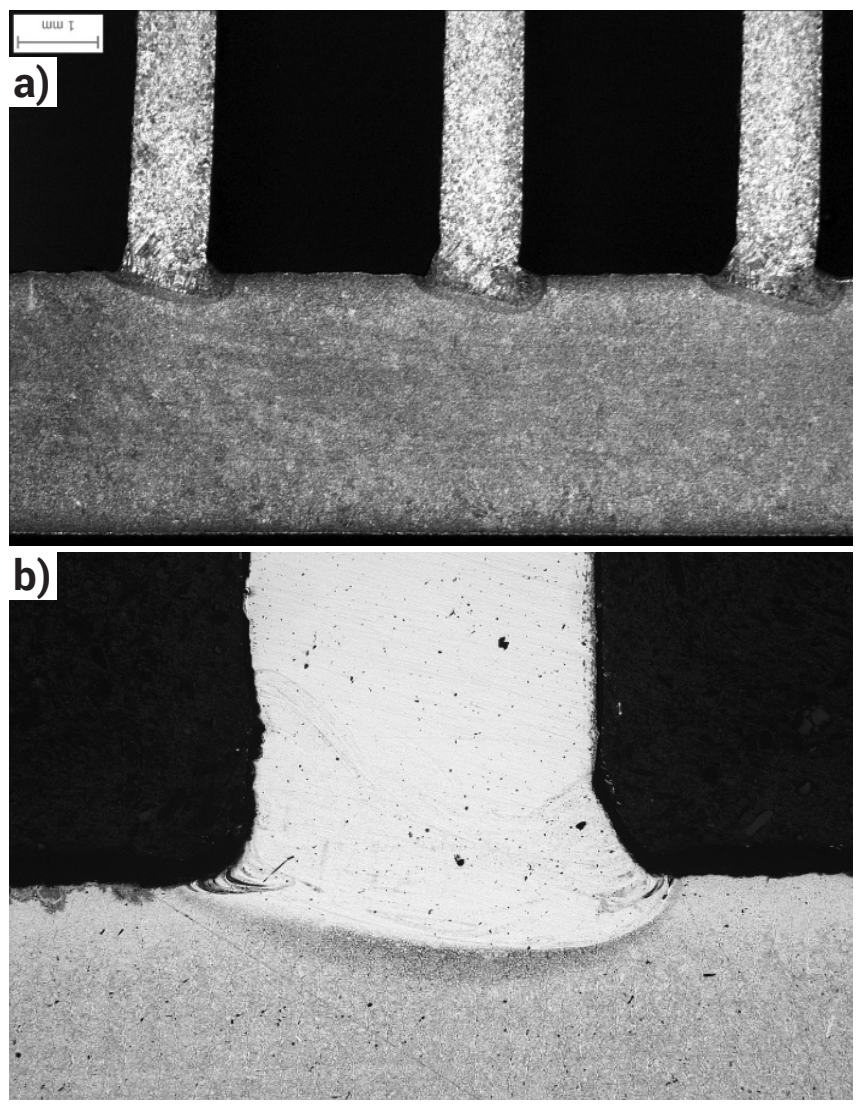

Rys. 3. a) Makrostruktura złącza wykonanego wiązką laserową o mocy 2,3 kW przy prędkości $80 \mathrm{obr} / \mathrm{min}$; b) makrostruktura połączenia

Fig. 3. a) Macrostructure of a welded joint made using a laser beam having a power of $2.3 \mathrm{~kW}$ at a rate of $80 \mathrm{rpm}$; b) welded joint macrostructure 
Badania mikrostruktury przeprowadzono na mikroskopie świetInym Olympus GX71 (LM) oraz na elektronowym mikroskopie skaningowym JEOL JCM-6000 Neoscope II (SEM) na zgładach trawionych w odczynniku Adlera. Wyniki badań mikrostrukturalnych pokazano na rysunku 4.

Mikrostruktura rury ze stali P91 jest typowa dla materiału po odpuszczaniu. W SWC stwierdzono gruboziarnistą strukturę martenzytycznej w układzie ziaren austenitu pierwotnego (rys. 4a). Natomiast w ferrytycznej strukturze spoiny widoczne są pasma niejednorodności składu chemicznego związane z mieszaniem się materiału spoiny podczas spawania (rys. 3b, 4b). Liniowa mikroanaliza składu chemicznego, wykonana metodą EDS wykazała, jednak nieznaczne zróżnicowanie składu chemicznego na linii przechodzącej od żebra przez spoinę do materiału rodzimego rury (rys. 5). Udział powierzchniowy pierwiastków jest jednak na poziomie składu chemicznego materiału rodzimego, co świadczy o prawidłowym procesie spawania zapewniającym odpowiednie właściwości żarowytrzymałości i żaroodporności złącza.
Uzupełnieniem badań metalograficznych była technologiczna próba statycznego rozciągania rury gładkiej ze stali P91, rury po spawaniu laserowym z usuniętym żebrem oraz rury po spawaniu laserem z taśmą (rys. 6a, 6b), próba udarności w temperaturze $20^{\circ} \mathrm{C}$ (rys. $6 \mathrm{c}, 6 \mathrm{~d}$ ) oraz pomiary twardości. Wyniki badań pokazano w tablicy II.

Analiza uzyskanych wyników technologicznej próby rozciągania wskazuje, że wytrzymałość rury gładkiej i rury po spawaniu laserowym z usuniętym żebrem jest na podobnym poziomie i wynosi odpowiednio $624 \mathrm{MPa}$ i $656 \mathrm{MPa}$. W przypadku rozciągania rury z żebrem spawanym laserem wytrzymałość wzrasta do $764 \mathrm{MPa}$, co jest spowodowane umocnieniem rury w wyniku dospawania żebra (tabl. II). Stwierdzono, że udarność materiału badana na niestandardowych próbkach o powierzchni przekroju $28 \mathrm{~mm}^{2}$ - zarówno dla rury gładkiej, jak również dla rury ożebrowanej po spawaniu laserowym - jest na podobnym poziomie, tj. w zakresie od $175 \mathrm{~J} / \mathrm{cm}^{2}$ do $185,7 \mathrm{~J} / \mathrm{cm}^{2}$ (tabl. II). Pomiary twardości wykazały jedynie utwardzenie w SWC od strony rury ze stali P91. Maksymalna zmierzona twardość tej strefy była na poziomie 315 HV (tabl. II). a)

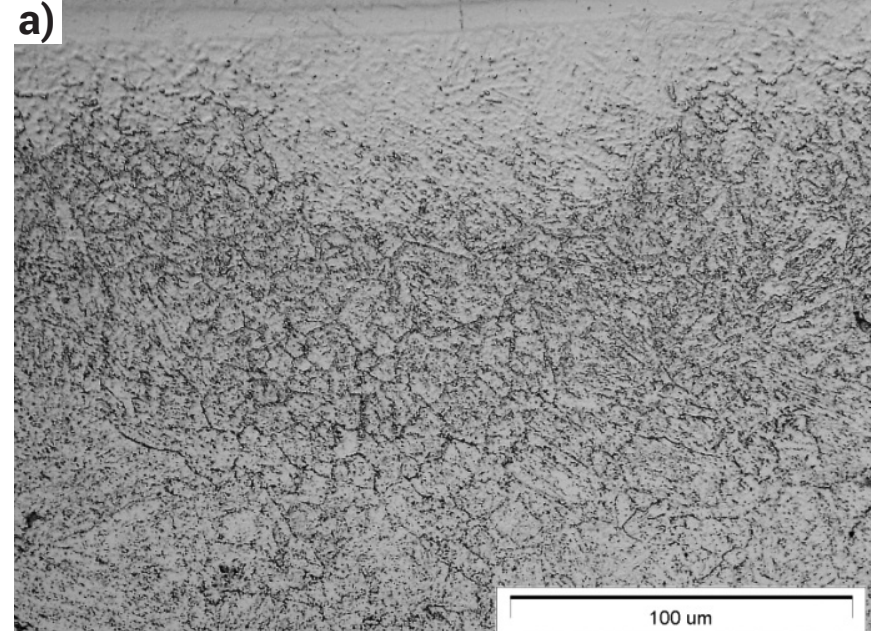

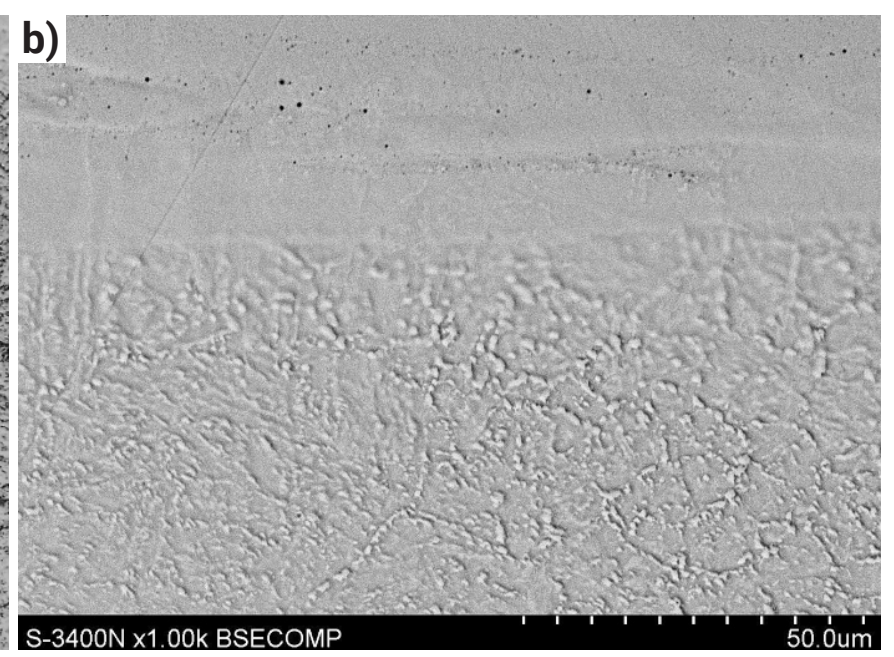

Rys. 4. a) Mikrostruktura złącza wykonanego wiązką laserową o mocy 2,3 kW przy prędkości 80 obr/min, LM; b) mikrostruktura na linii wtopienia od strony materiału rury P91, SEM

Fig. 4. a) Microstructure of a welded joint made using a laser beam having a power of $2.3 \mathrm{~kW}$ at a rate of $80 \mathrm{rpm}$, LM; b) microstructure at the fusion line on the P91 tube side, SEM
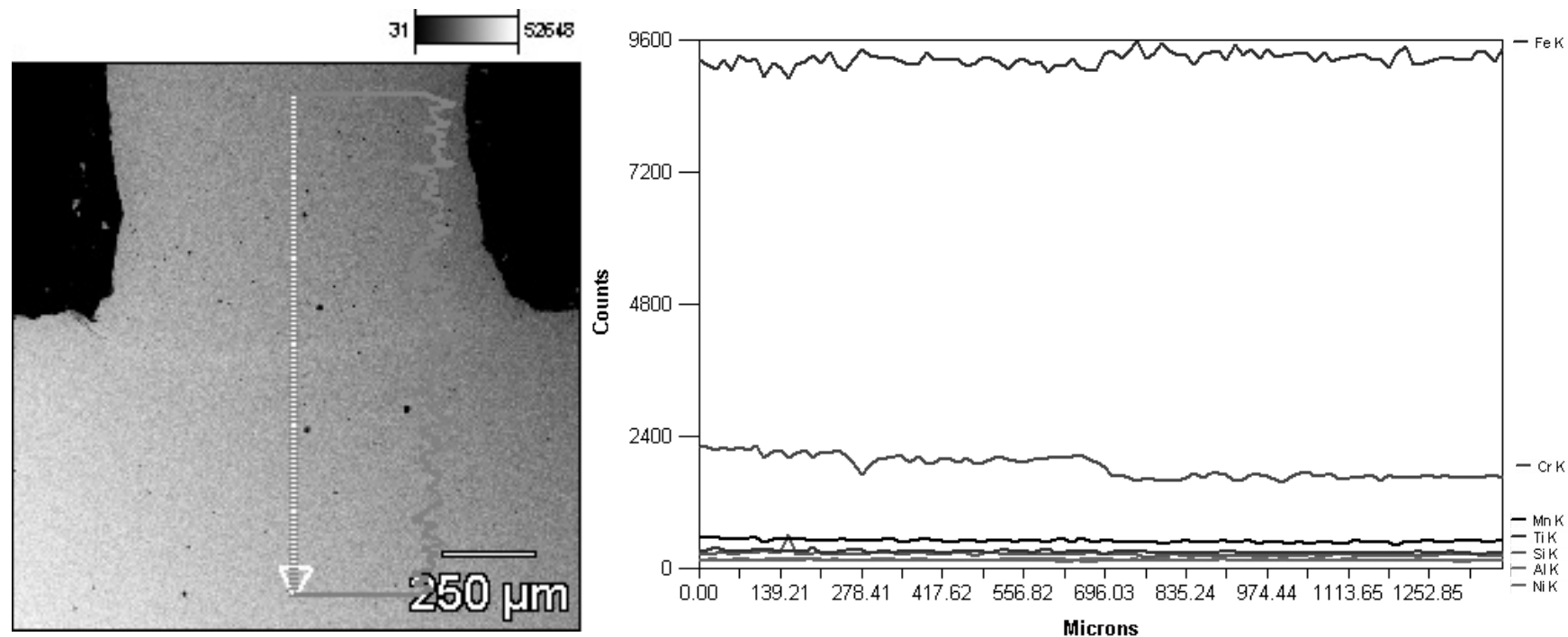

Rys. 5. Wyniki liniowej mikroanalizy składu chemicznego EDS złącza spawanego laserowo rury ożebrowanej ze stali P91 Fig. 5. Results of the EDS linear microanalysis of the chemical composition of a laser-welded joint on a P91 finned tube 
Tablica II. Wyniki oceny właściwości mechanicznych połączenia rura - żebro

Table II. Results of the assessment of the mechanical properties of the tube - fin joints

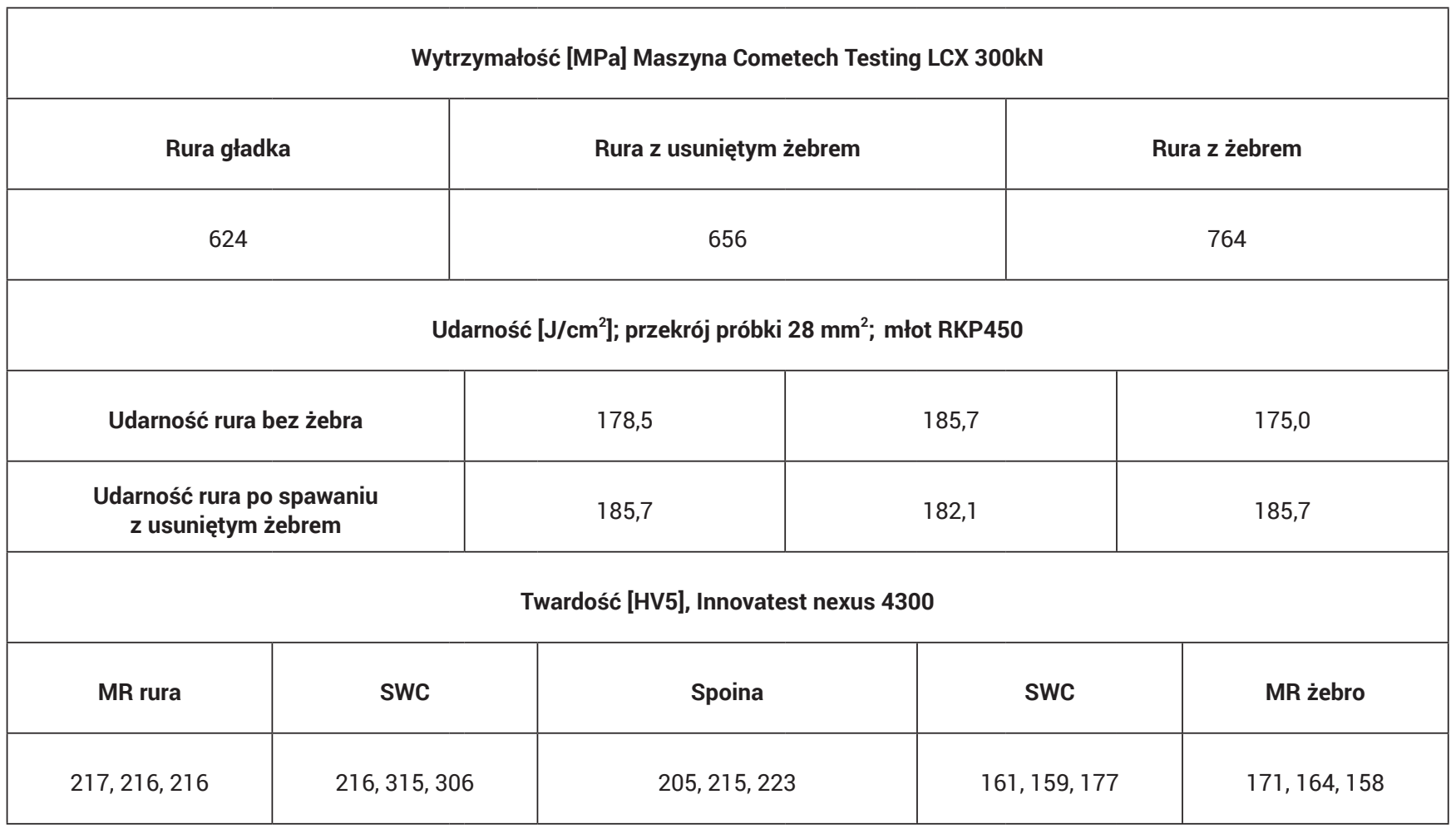

a)

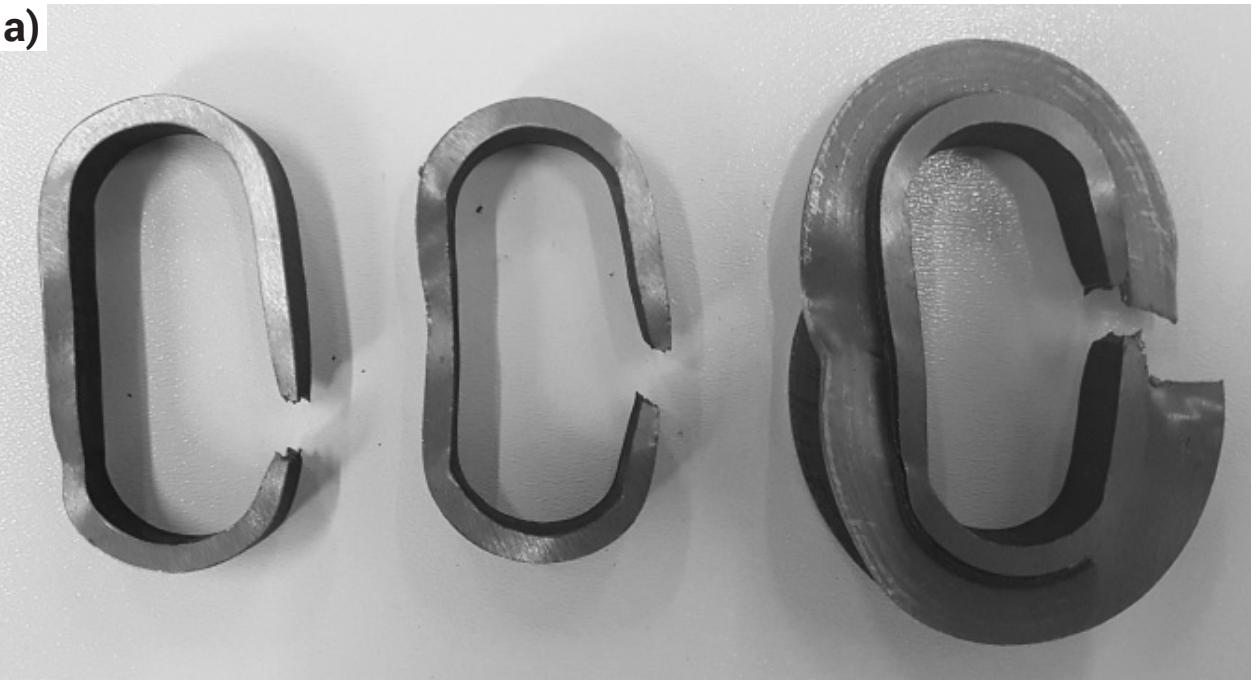

c)
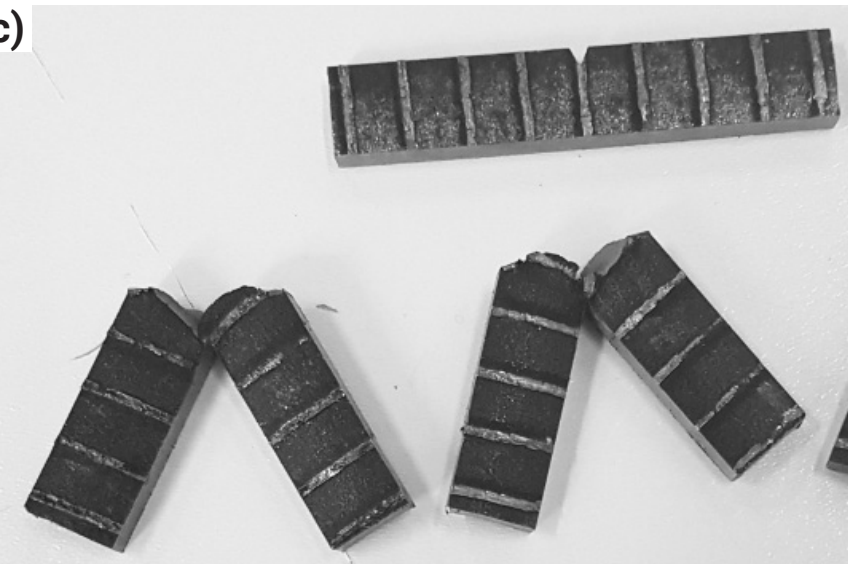

b)

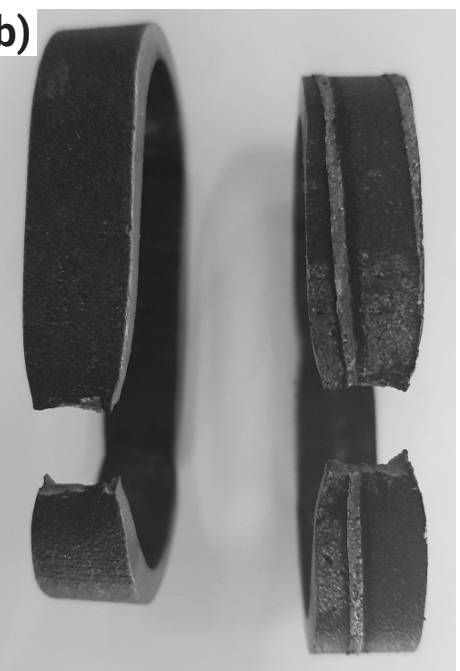

d)

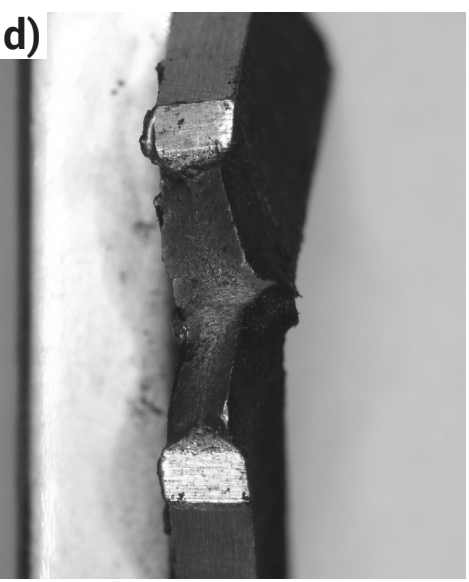

Rys. 6. Próbki po badaniach właściwości mechanicznych połączenia: a, b) próbki po technologicznej próbie rozciągania rur; c, d) próbki po badaniach udarności

Fig. 6. Specimens after the tests of the mechanical properties of the welded joints: $a, b)$ specimens after the technological tensile strength tests; c, d) specimens after the impact tests 


\section{Podsumowanie}

Zastosowanie spawanych rur ożebrowanych w urządzeniach energetycznych prowadzi do oszczędności energii i obniżki kosztów w procesie eksploatacji kotłów przemysłowych, odzyskiwania ciepła kondensacji i jego celowego wykorzystania oraz minimalizacji strat energii poprzez obniżenie temperatury gazów spalinowych. Istnieje kilka technologii wytwarzania rur ożebrowanych dla przemysłu energetycznego (rys. 1). W Energoinstal SA opracowano innowacyjną technologię spawania laserowego rur ożebrowanych (rys. 2).

Wymagania stawiane nowoczesnym konstrukcjom kotłów powodują konieczność stosowania wyższych parametrów pracy tj. ciśnienia i temperatury (kotły na parametry nadkrytyczne i ultranadkrytyczne). Jest to związane z koniecznością stosowania materiałów o zaawansowanych właściwościach, szczególnie żarowytrzymałości i żaroodporności. Warunki te spełnia stal P91. Jest to stal obecnie stosowana w kotłach o parametrach nadkrytycznych na rurociągi i komory wymienników. Dobra żarowytrzymałość i żaroodporność stali P91 wskazuje, że jest to materiał o dużym potencjale wykorzystania w konstrukcjach wymienników ciepła zbudowanych z rur ożebrowanych.

Przeprowadzone w Centrum Innowacyjnych Technologii Laserowych Energoinstal SA próby technologiczne spawania laserowego rur ożebrowanych o średnicy 38x2,9 mm z żebrem ciągłym 15x1,0 mm ze stali P91 wykazały możliwość prawidłowego wykonania ciągłego złącza z pełnym przetopieniem. Otrzymane złącze spełnia wymagania klasy jakości B wg PNEN ISO 13919 (rys. 3, rys. 4). W pracy przedstawiono tylko część wyników ze względu na objętość referatu. Analiza wszystkich wyników wskazuję, że rury ożebrowane ze stali P91 należy spawać na zautomatyzowanych stanowiskach laserowych z prędkością obrotową od 80 do 100 obr/min, wiązką laserową o mocy od 2,3 do 2,8 kW.

Analiza struktury złącza rura-płaskownik ujawniła w spoinie wymieszanie materiału stali P91 z materiałem żebra, jednak to wymieszanie jest na akceptowalnym poziomie (rys. 5). Analiza struktury i właściwości mechanicznych rury ożebrowanej spawanej laserem w Energoinstal SA nie ujawniła niezgodności spawalniczych a wytrzymałość oraz udarność, badane w próbach porównawczych do rury gładkiej, są na podobnym poziomie (rys. 6). Rozkład twardości w złączu wykazał utwardzenie w SWC od strony rury P91, jednak twardość w tej strefie nie przekroczyła 315 HV (tabl. II).

Przeprowadzone badania wskazują, że opracowana w Energoinstal SA może być podstawą do kwalifikowana zgodnie z PN-EN ISO 15614-11. Ważnym elementem dalszych badań jest określenie wpływ obróbki cieplnej po spawaniu na strukturę i właściwości złącza. Uzyskane wyniki badań porównawczych dla rury gładkiej i rury ożebrowanej spawanej laserem są podstawą do analizy konieczności stosowania pospawalniczej obróbki cieplnej.

\section{Literatura}

[1] J. Topolski, J. Badur. Comparison of the Combined Cycle Efficiencies With Different Heat Recovery Steam Generators, the paper submitted to "Transactions of Institute of Fluid-Flow Machinery" , pp. 1-12, 2000.

[2] F. J. Mengede, K.D. Tigges, M. Farley, M. J. Duarte: Power market, technologies and acceptance: Status and perspectives, VGB Powertech 1/2/2012.

[3] K. Mizielińska, J.Olszak: Parowe źródła ciepła, WNT 2009.

[4] W. Sobbe, J. Janzen, M. Schiemann, H. Braun: Effiziente Dampfkesselanlagen fuer industrielle Heiz- und Heizkraftwerke sowie Hilfskesselanlagen fuer Kraftwerke, , VGB Powertech 7/2011.

[5] P. Adamiec, J. Ochman, H. Polubniok, W. Voss: Wpływ wadliwości rur ożebrowanych na ich sprawność termiczną, Nowe technologie i materiały w metalurgii i inżynierii materiałowej, II Seminarium Naukowe Wydział Inżynierii Materiałowej i Metalurgii, Politechnika Śląska, Katowice 2004.

[6] J. Adamiec: Porównanie charakterystyk kotłów dla EC Gorzów, Materiały niepublikowane Energoinstal SA 2013.

[7] J. Adamiec, Projekt PBS1/A5/13/2012: Technologia spawania laserem rur ożebrowanych ze stali austenitycznych i stopów niklu przeznaczonych do pracy w kotłach o parametrach nadkrytycznych i ultranadkrytycznych, projekt finansowany przez NCBiR w ramach Programu Badań Stosowanych, 2012-2015.

[8] M. Więcek: Wpływ technologii spawania na strukturę i właściwości rur ożebrowanych dla przemysłu energetycznego, Rozprawa doktorska, Politechnika Śląska, Wydział Inżynierii Materiałowej i Metalurgii, Katowice 2014. 